\title{
An Open Letter to the APSA Leadership and Members
}

As many of you are aware, the American Political Science Association has recently experienced an extraordinary outpouring of frustration with the current state of the American Political Science Review, the APSA, and the profession generally. An anonymous scholar writing as "Mr. Perestroika" circulated to an extensive roster of political scientists a passionate memo asking many provocative, indeed painful, questions. Why do so many leaders of our profession not even read, much less submit, to the APSR? Why is purchase of the $A P S R$ made mandatory for membership, thus subsidizing a journal many find unsatisfactory, instead of permitting membership without the journal or with other journals? Why do the APSA Council and APSR Editorial Board seem to be chosen essentially by their predecessors? Why does the APSR and why do other prominent professional fora seem so intensively focused on technical methods, at the expense of the great, substantive political questions that actually intrigue many APSA members, as well as broader intellectual audiences?

Though some recipients may have felt uncomfortable with the anonymous authorship and the highly polemical tone of this post, nonetheless an astonishing number of scholars, from all ranks of the profession, felt impelled to announce that they, too, shared these profound dissatisfactions with the status quo. Many noted that in 1998 an APSA membership survey reportedly found that, in fact, a very large proportion of APSA members, to say nothing of scholars who have given up on APSA, were critical of the current condition of the APSR. A lively discussion ensued, in which scholars discussed whether the problems arose from the biases of APSR editors and APSA leaders, from more structural problems in the reviewing processes, or from problems in Ameri-

\section{Editor's Note}

In September 1999, the APSA Council initiated a Strategic Planning Process [www.apsanet.org/new/ planning//. According to 19992000 APSA President Robert Keohane, the purpose of strategic planning was to "evaluate the overall condition of the Association relative to its mission and key challenges and opportunities in the external environment; to analyze APSA's strengths and weaknesses, including its financial strengths and weaknesses; to make recommendations on the most pressing issues or critical choices that must be made, including those pertaining to membership, revenues, services, and publications" (www.apsanet.org/new/ planning/statement.cfm). Over the course of the next 12 months, the Strategic Planning Committee chaired by Paul Beck of Ohio State University issued three preliminary reports

(www.apsanet.org/new/ planning/) and a final report published in this issue of PS.

Over the same period, the Council appointed a search committee to select a successor to APSR Editor Ada Finifter, whose second term is slated to end August 2001. (Her annual report appears in this issue of PS). The search committee, chaired by Peter Gourevitch of the University of California, San Diego, working with a highly competitive list of 17 individual and team applications, enthusiastically recommended Lee Sigelman of George Washington University to President Keohane and the APSA Council. Sigelman was unanimously approved by the Council in September 2000 (see the announcement in this issue of PS).

Even before the Strategic Planning Committee or the search committee had completed their work, the APSA Council initiated in April a change in the Association's bylaws to provide for the Council's advice and consent to the editor's nominees for the APSR Editorial Board.

At its August 2000 meeting, the Council decided to develop a new journal or new content in the $A P S R$, either in print or electronic format, that would feature book reviews, review essays, and policy-related articles, and charged a Publications Implementation Committee with making the new journal a reality no later than January 2003.

There has been a remarkable level of member participation in strategic planning in focus groups held at regional meetings, in Hyde Park sessions offered during the 2000 Annual Meeting, in print and email submissions to the relevant committees, in email discussion groups, and even the public press. Even now, the debate continues. In the spirit of providing a venue for open discussion of issues of concern to the Association's members, a selection of comments received after the planning committee ended its work is available of the APSA web site (www.apsanet.org/new/ comments.cfm). In this issue, the debate continues with these articles and recent additions to the debate. Future issues will continue to cover the discussion and your comments are invited.

November 7, 2000

\section{Talking Strategic Planning Online}

An additional collection of comments and discussion regarding APSA, APSR and the Strategic Planning process are available online at

www.apsanet.org. 
can intellectual and political life more broadly. Inevitably, people differed in their views. There has been, however, extensive agreement that whatever the sources of the problems, changes need to be made.

What changes? Many ideas have been explored in recent email discussions. These have included:

- Permitting APSA members not to purchase the APSR, but rather to choose alternative journals or none at all.

- Making the selection of the APSR Editorial Board, the APSA Council, and basic policy decisions concerning the journal and the association more open to genuine democratic decision making by the APSA membership.

- Revising the APSR reviewing process to seek both to ensure that some methodologies are not automatically vetoed and that most articles are of interest to a broad scholarly audience.

- Finding ways to encourage scholars who have given up on the APSR to submit their work to it once again.

- Pursuing the suggestions both for an electronic APSR and a separate "book reviews" journal that the Association's Strategic Planning Committee has raised.

- Making the 1998 survey of attitudes toward the APSR widely available, and, yet more importantly, developing mechanisms to examine regularly how satisfied political scientists are with the publications and professional activities they underwrite via their APSA dues.

It is very unfortunate that deeply committed political scientists genuinely believe, whether rightly or wrongly, that they cannot criticize the status quo safely without the cloak of anonymity. We should have regular channels through which dissent can be effectively communicated.

We, the undersigned, do not represent any consensus on just why the APSR and the APSA are in the condition they are now in, nor any consensus on just what should be done. We are also not an organized or systematically recruited group. We are simply scholars who, after discussing the Perestroika memo over the course of a few days, decided to join in this letter. We do so because we believe strongly that the profession is in danger of alienating a larger and larger number of those who should be its active members, and contributing less and less to the kinds of understanding of politics that it is our responsibility to advance. Hence, we urge the APSA leadership and membership alike to look seriously at the issues raised above, to speak out on them, and to take soon the actions that emerge as most widely endorsed in the ensuing discussions.

Christopher S. Allen, University of Georgia Belinda A. Aquino, University of Hawai' $i$, Manoa

Myron Aronoff, Rutgers University

Robert Art, Brandeis University

Zoltan D. Barany, University of Texas, Austin

Bethany Barratt, University of California-Davis David M. Barrett, Villanova University

Deborah Baumgold, University of Oregon

Seyla Benhabib, Harvard University

Thomas U. Berger, Johns Hopkins University

Gerald Berk, University of Oregon

Larry Berman, University of California

Washington Center

Sheri E. Berman, Princeton University

Michael Bernhard, Penn State University

Richard K. Betts, Columbia University

Jack Bielasiak, Indiana University

Marc Blecher, Oberlin College

Mark Blyth, Johns Hopkins University

John Bokina, University of Texas, Pan

American

Joe Bowersox III, Williamette University

Paul R. Brass, University of Washington

Stephen Eric Bronner, Rutgers University

Christopher Brooke, Magdalen College, Oxford University

Wendy Brown, University of California, Berkeley

Fran Buntman, University of Akron

Susan Burgess, Ohio University

Bert C. Buzan, California State University,

Fullerton

Keith J. Bybee, Harvard University

Joseph Carens, University of Toronto

Barbara J. Callaway, Rutgers University

Lief H. Carter, Colorado College

Haesook Chae, Baldwin Wallace College

Geeta Chowdhry, Northern Arizona University

Cornell Clayton, Washington State University

Eliot A. Cohen, Johns Hopkins SAIS

Stephen Crowley, Oberlin College

Bruce Cumings, University of Chicago

Jodi Dean, Hobart and William Smith Colleges

Thomas DeLuca, Fordham University

Michael C. Desch, University of Kentucky

Gus diZerega, Whitman College

Raymond Duvall, University of Minnesota

Tim Duvall, St. John's University

David V. Edwards, University of Texas, Austin
John Ehrenberg, Long Island University Fred Eidlin, University of Guelph Richard J. Ellis, Willamette University Edward C. Epstein, University of Utah Peter Euben, University of California, Santa Cruz

Daryl R. Fair, College of New Jersey

Richard A. Falk, Princeton University

Tom Farer, University of Denver

Kathy E. Ferguson, University of Hawai' $i$

Leela Fernandes, Rutgers University

Joel Fetzer, Central Michigan University

Stephen L. Fisher, Emory \& Henry College

James C. Foster, Oregon State University

Samantha Frost, University of Illinois, Champaign-Urbana

John Gerring, Boston University

Edward Gibson, Northwestern University

Howard Gillman, University of Southern

California

Robert S. Gilmour, University of Connecticut

Jon Goldberg-Hiller, University of Hawai' $i$

Emily O. Goldman, Joint Center for

International and Security Studies

Marie Gottschalk, University of Pennsylvania

Judith Grant, UCLA

Lowell Gustafson, Villanova University

Peter A. Hall, Harvard University

Anne M. Hallum, Stetson University

Stephen E. Hanson, University of Washington

Paul Harris, London Guildhall University

Dennis Hart, Kent State University

Victoria Hattam, New School for Social Research

Alice Hearst, Smith College

Daniel Hellinger, Webster University

Clement M. Henry, University of Texas, Austin

Gary Herrigel, University of Chicago

Eric Hershberg, Social Science Research Council

Elisabeth Hilbink, Princeton University

Jennifer Hochschild, Harvard University

Bonnie Honig, Northwestern University

Marc Morjé Howard, University of California,

Santa Cruz

Chris Howell, Oberlin College

Patrick Thaddeus Jackson, American University

Laura Jensen, University of Massachusetts-

Amherst

Alana S. Jeydel, Oregon State University Robert M. Johnstone Jr., Earlham College Gregory Kasza, Indiana University

Lyn Kathlene, University of Nebraska-Lincoln

Stuart Kaufman, University of Kentucky

Chaim Kaufmann, Lehigh University

Margaret Keck, Johns Hopkins University

Thomas M. Keck, University of Oklahoma

Marisa Kelly, University of the Pacific

Paul Kens, Southwest Texas State University

Jennet Kirkpatrick, Rutgers University

Ramsey Kleff, Virginia Union University

Philip A. Klinkner, Hamilton College

Audie Klotz, University of Illinois, Chicago

Donald P. Kommers, Notre Dame Law School

Jeffrey S. Kopstein, University of Colorado, Boulder

Henry Krisch, University of Connecticut

Sankaran Krishna, University of Hawai' $i$, Manoa

Judy B. Krutky, Baldwin-Wallace College

Jan Kubik, Rutgers University 
Joseph LaPalombara, Yale University

Susan E. Lawrence, Rutgers University

David Lempert

Frederick Lewis, University of Massachusetts

Lowell

Roy Licklider, Rutgers University

Keir Lieber, Georgetown University

Robert J. Lieber, Georgetown University

Tracy Lightcap, LaGrange College

Ann Chih Lin, University of Michigan

Timothy W. Luke, Virginia Tech

William M. Lunch, Oregon State University

Patricia Maclachlan, University of Texas, Austin

Scott Mainwaring, University of Notre Dame

Anne Manuel, University of Michigan

Gregory B. Markus, University of Michigan

Anthony Marx, Columbia University

Mark Mattern, Baldwin Wallace College

Kenneth R. Mayer, University of Wisconsin-

Madison

Michael W. McCann, University of Washing-

ton, Seattle

Kirstie M. McClure, UCLA

John Mearsheimer, University of Chicago

Sarah E. Mendelson, Tufts University

Jonathan L. Mercer, University of Washington

Joel S. Migdal, University of Washington

James Morone, Brown University

Gary Mounce, University of Texas, Pan

American

Tamir Moustafa, University of Washington,

Seattle

Gerardo Munck, University of Illinois, Champaign-Urbana

Jamal Nassar, Illinois State University

Thomas M. Nichols, U.S. Naval War College

Miko Nincic, University of California-Davis

Anne Norton, University of Pennsylvania

Julie Novkov, University of Oregon

William R. Nylen, Stetson University

J. Eric Oliver, Princeton University

Laura K. Olson, Leigh University

Melissa A. Orlie, University of Illinois, Urbana-Champaign

Robert Pape, University of Chicago

Michael Paris, Rutgers University

Anthony Pereira, Tulane University
V. Spike Peterson, University of Arizona

Paula Pettavino, American University

Daniel Philpott, University of California,

Santa Barbara

Paul Pierson, Harvard University

David Pion-Berlin, University of California, Riverside

Robert Price, University of California, Berkeley

Adolph Reed Jr., New School for Social Research

Howard Reiter, University of Connecticut

Edward Rhodes, Rutgers University

Gretchen Ritter, University of Texas, Austin

Edward Ian Robinson, University of Michigan

Gideon Rose, Foreign Affairs

Srirupa Roy, University of Massachusetts-

Amherst

Arthur Rubinoff, University of Toronto

Lloyd Rudolph, University of Chicago

Susanne H. Rudolph, University of Chicago

Kim Lane Scheppele, University of Pennsylva-

nia Law School

David Schlosberg, London School of

Economics

Ben Schneider, Northwestern University

Cathy Schneider, American University

Thomas S. Schrock, University of California,

Santa Barbara

David Schultz, Hamline University

Donald L. Scruggs, Stephens College

James C. Scott, Yale University

Anna Seleny, Princeton University

William Sewell, University of Chicago

Ian Shapiro, Yale University

Samer Shehata, New York University

Clare Sheridan, University of California,

Berkeley

George Shulman, New York University

Gary Shiffman, University of California, San Diego

Stuart W. Shulman, Drake University

Diane Singerman, American University

Patricia D. Siplon, Saint Michael's College

Theda Skocpol, Harvard University

Stephen Skowronek, Yale University

Marion Smiley, University of Wisconsin, Madison
Cortlandt Smith, University of the Pacific

Rogers M. Smith, Yale University

Zachary A. Smith, Northern Arizona

University

Jeannie Sowers, Princeton University

Valerie Sperling, Clark University

Robert J. Spitzer, SUNY Cortland

Tracy B. Strong, University of California, San Diego

Brent S .Steel, Oregon State University

Sherrill Stroschein, Ohio University

Narendra Subramanian, $M c$ Gill University

Liz Suhay, University of Michigan

Carl Swidorski, The College of Saint Rose

Susette M. Talarico, University of Georgia

Nina Tannenwald, Brown University

Daniel Tichenor, Rutgers University

Charles Tilly, Columbia University

Aili Mari Tripp, University of Wisconsin, Madison

Jeffrey Tulis, University of Texas, Austin

Stephen Van Evera, MIT

Ashutosh Varshney, University of Notre Dame

Robert Vitalis, University of Pennsylvania

James L. Walker, Wright State University

Thomas C. Walker, University at Albany-SUNY

Stephen M. Walt, Harvard University

Artemus Ward, California State University,

Chico

Dorian Warren, Yale University

Lisa Wedeen, University of Chicago

Paul I. Weizer, Fitchburg State College

Donald Will, Chapman University

Eliza J. Willis, Grinnell College

Elizabeth Wingrove, University of Michigan

Alexander Wendt, University of Chicago

William C. Wohlforth, Dartmouth College

Meredith Woo-Cumings, Northwestern University

Charlotte Wood, Rutgers University

Ken Woodside, University of Guelph

McGee Young, Syracuse University

Sara L. Zeigler, Eastern Kentucky University

Linda Zerilli, Northwestern University

Cyrus Ernesto Zirakzadeh, University of Connecticut

November 3, 2000

\section{"Technicism" Supplanting Disciplinarity among Political Scientists}

I write to express my support for the spirit if not all the particulars of the Perestroika protest letter concerning the representativeness of APSA and its journals. In my view this question should be settled democratically via the market and the voting booth.

To assure the representativeness of the APSA leadership, which is the real issue behind the Perestroika protest, there should be competitive, membership-wide elections to the top posts. Put multiple candidates on the ballot and publish statements of their ideas concerning political science and the Associa- tion. If it is clear that the organization's leaders represent a majority of the membership, the issues of legitimacy raised by Perestroika will have been addressed in perhaps the fairest way possible. Allow us to choose, instead of having an appointed nominating committee select leaders in a closed discussion to which the mass membership is not privy. The results may show that Perestroika is right or wrong about mass disenchantment with the Association. Let the chips fall where they may. But in my view, the problem here is not just with results, it is with the organizational procedures that produced those results.

As for the $A P S R$, my preference is to separate the book review section from the journal, make the book review publication longer and more comprehensive (including a few review articles), and circulate the book review journal only to all members. Let the APSR fend for itself on the subscribers' market. I suspect that the APSR will either change its colors or it will lose its preeminent status and become just one of many good publications in political science that caters to a select constituency. Whether this or 
any other change is to be made, however, should not be decided by the APSA Council or an executive committee. It should be put to the entire membership for a vote. What possible objection could be raised to that? We are only asking that political scientists be allowed to make a rational choice as to what it is in their interests to read, and to enjoy the prerogatives of democratic citizens everywhere.

I should be specific about why I consider the reform of APSA and the APSR to be desirable, even if such reform is not in my view a panacea for the ills afflicting the profession.

There is a "technicism" prevalent in political science research that is hardly limited to rational choice, statistical analysis, or APSA's journals, though it certainly flourishes in the latter. The preoccupation with method and research design has taken precedence over contributions to knowledge about politics. The means of our work have somehow become more important than the end. It is reminiscent of medieval Catholicism, when the form of the sacraments became a bigger concern than leading a virtuous life. Political science is in need of a Protestant Reformation. But this technicism is common to many of the journals people have cited as praiseworthy alternatives to the APSR, not only in the latter. Whether referees like my work or not, nearly all of the praise and blame I read any more is related to research design, with nary a word about whether I have added something worthwhile to our knowledge of politics.

What is the source of this technicism? Is it that the end of the Cold War has made substantive political issues less compelling? Is it due to the demise of classical political philosophy as a standard part of our graduate education? Whatever its other causes, I think that this technicism reflects a vain attempt to restore some sort of coherence to a "discipline" whose diversity has robbed it of any substantive focus.

The presentations that I heard at the recent APSA meetings concerning the state of the discipline (ostensibly the topic of the conference) were of the fiddling-whileRome-burns variety, ignoring the obvious fact that political scientists qua political scientists have nothing in common anymore. As Sidney Verba commented at the Atlanta meeting, once upon a time there were four or five books published every year that all political scientists would read, but today there aren't any. Another reflection of the discipline's lack of a center is that the "innovations" that occur in political science these days usually reflect only the discovery of one part of the discipline by another, rather than anything really fresh. I suspect that some of the frustrations with the refereeing process at journals derive from this lack of focus--the referees for a given piece today often have not read the same books as the author and are not interested in the same topics, even when they hail from the same subfield. This is not exclusively a problem of the APSR, and it must make the editor's task of selecting readers at any journal all but impossible.

Whatever the source of the technicism that reigns in political science, it disturbs me that increasingly I read research that seems unmotivated by any substantive interest in politics (i.e., the kind of politics that goes on outside the window). The author appears to have chosen a topic merely for its utility to test drive some method, model, or approach. Although the APSR is hardly the only journal that features such work, I agree with those leading the Perestroika protest that the APSR has a special responsibility to be representative of the chaos that prevails in the "discipline" and not the mouthpiece of a few cliques.

Thus, I endorse the idea that the APSR should have to sell subscriptions in the marketplace, or, barring that solution. that its governance be radically overhauled. And I suggest that this issue as well as the selection of APSA's leaders be decided in a more democratic manner by the membership as a whole.

\section{Gregory J. Kasza,} Indiana University

The following participants in the Perestroika forum have expressed via email their desire to co-sign this letter.

Christopher S. Allen, University of Georgia Jack Bielasiak, Indiana University Paul R. Brass, University of Washington Joseph H. Carens, University of Toronto Kiren Aziz Chaudhry, University of California, Berkeley

Gary Herrigel, University of Chicago

Bonnie H. Honig, Northwestern University

Chris Howell., Oberlin College

Stuart Kaufman, University of Kentucky Margaret E. Keck, Johns Hopkins University

Jeffrey S. Kopstein, University of Colorado, Boulder

Timothy W. Luke, Virginia Tech Gretchen Ritter, University of Texas, Austin James C. Scott, Yale University

Anna Seleny, Princeton University

Samer Shehata, New York University

Dorothy Solinger,

Charles Tilly, Columbia University

November 3, 2000

\section{APSR a Reflection of Its Submissions for Better and Worse}

\author{
[Gregory Kasza's letter of \\ November 3] raises a number of \\ important issues that need to be \\ addressed by our membership and \\ deliberated by the APSA commit- \\ tees and Council, but here I'd just \\ like to provide some information on \\ the Council's decisions in August,
}

some of which responded to the position [Kasza takes], which was conveyed to and shared by the Strategic Planning Committee.

I believe that the SPC said that it believed that what was published in the Review did not represent the range of excellent work done across the discipline. I know that this is my view and, more importantly, that it is the view of Lee Sigelman, who has just been selected as the new editor of the Review. (It may be worth noting that he was the unanimous choice of the selection committee chaired by Peter 
Gourevitch, whose other members were myself, Gary King, Arlene Saxenhouse, and Katherine Tate.) Furthermore, although we lack good data, everyone I talk to believes that this skewing of the accepted essays reflects not-or at least not so much-biases in the referees but rather the self-selection process of what is submitted. Anticipated reactions and selffulfilling prophecies are familiar to us and seem to be very strongly at work here. [Sigelman] explained to the Council that he will work to break this cycle, and I hope you will help him in this endeavor.

[Sigelman] also stressed to the selection committee and to the Council his commitment to seeing that articles in the Review are accessible to as many of our members as possible. He believes - as I do - that even "technical" articles can be written in a way that explains their significance to scholars who use different approaches and are interested in different substantive questions.

The Council also passed the following resolution:

\section{Rethink APSR Review Policy}

APSA president Robert Jervis has written to the Perestroika forum avowing his support for the goal of expanding the range of articles carried by the $A P S R$. He further noted that APSA's strategic planning committee and the incoming editor, Lee Sigelman, also embrace this goal. But his letter suggests that the self-selection of contributors was the main reason for the $A P S R$ 's unbalanced contents and, other than the good intentions of all concerned, he offered no plans for structural change in the journal. I am grateful that Professor Jervis shares some of the goals of the Perestroika forum, but I ... take issue with some of his points and urge a more concrete and active program of change.

The contention that APSA's skewed publication of articles is entirely a product of self-selection is not persuasive. If scholars in
The APSA will publish expanded book reviews and more integrative essays no later than January 2003 in a form--electronic and/or print, in an existing or new publication-to be decided. An ad hoc Publications Implementation Committee, appointed by the president and approved by the Council will be established to recommend to the Council plans to carry this out. The committee will report to the Council at its next meeting, April 21, 2001, and will have a completed plan in place for Council approval in time for its August 29, 2001 meeting.

By "integrative essays" the Council has in mind both essays that review the literature in an area and articles that are less specialized than our normal research and span larger parts of the discipline. The latter might also involve the application of political science to questions of public policy.

If you have followed the discussions of the SPC you will also know that one advantage of electronic publication would be the ability to run longer pieces, which would benefit several styles of research.

some fields have stopped sending manuscripts, it is because they perceived a prior bias against their work in the Review's editorial policy. Professor Richard Betts outlined most of the problems with the APSR to the APSA Publications Committee in 1991 in a memo that has circulated via the Perestroika forum. If the APSR's editorial staff were not biased in favor of certain forms of research, how does one explain that the staff has done nothing to remedy the situation in the nine years since? My purpose here is not to rebuke those responsible for past mistakes, but to foster an appreciation of the need for structural reform, and not merely a statement of good intentions in the present.

I am further concerned that Professor Jervis's description of an alternative future policy for the APSR, which echoes the views of
I'd like to make two other observations. First, there are strong criticisms of the Review from those who see it as insufficiently rigorous and scientific and who think the AJPS is the model to follow. I disagree, but any full dialogue and deliberative process must of course include these colleagues.

Second many of the problems stem less from the narrowness of the Review itself than from the combination of this and the fact that some departments and university administrations insist on publication in the Review as a crucial criterion for tenure or promotion. I regard this as an abdication of the responsibility to judge work on its scholarly merits. There are a wide range of excellent and highly selective journals and presses and we an argue about the size of the correlation between the prestige of an outlet and the quality of any one piece that it issues, but no one would claim that it is perfect.

APSA President Robert Jervis, Columbia University

November 4, 2000

many contributors to the Perestroika forum, may actually serve to sustain the journal's current vices. Several people have pointed to a "general interest" doctrine as a praiseworthy alternative to current policy, i.e., each article should be of general interest to political scientists in different fields. In addition to ideological biases, however, it is the selective implementation of just such a general interest doctrine that accounts for -much of the APSR's de facto discrimination against soft-science research. Let me explain my reasoning.

I can imagine only two possible editorial policies for the journal.

\section{Policy \#1}

To publish the best research in any field of political science. This policy would require that every manuscript go exclusively to 
referees in the same field as the author. An article on Japanese politics would go to three experts on Japanese politics, a quantitative study of American politics would go to three scholars doing that type of work, and so forth.

\section{Policy \#2}

To publish research that is of the broadest possible interest to political scientists in different fields.

This policy would require that the referees for each manuscript include people inside and outside the author's field. An article on Japanese politics might go to one referee in that field, to another in some other subfield of comparative politics, and to a third outside comparative politics altogether.

I think that the APSR has been applying both policies simultaneously, but in a selective manner. In regard to complex quantitative studies, rational choice and other types of deductive theory, formal modeling, and (ironically) research in classical political philosophy, the Review has been applying policy \#1. The editor thinks, "If I send this complex mathematical analysis or this manuscript on Hegel to referees in other fields, they will not be able to pass informed judgment." Such manuscripts thus go to three experts. But when a soft-science manuscript on the French party system or ChineseRussian relations comes in, the editor applies policy \#2, thinking: "This is written in (more or less) plain English, so I'll send it to referees inside and outside the author's field to see if it is of general interest." The result? Manuscripts subject to policy \#1 get published in disproportionately high numbers compared to those that must jump the higher bar of policy \#2. (Betts found that "quantitative research, game theory, and formal modeling comprise the nearly exclusive content of the journal apart from articles in political philosophy.")

Professor Jervis, Rogers Smith, and other contributors to the forum have suggested that a uniform general interest doctrine (policy \#2) might put the Review on the right path. I respectfully disagree. The only way to level the playing field is to implement policy \#1 for all manuscripts, demanding that each author pass muster with three experts in the same field. Why? Because there are not enough manuscripts of general interest published anywhere in political science each year to fill even one edition of the APSR. It is irrelevant whether we would like there to be more; the fact is that there are not. I ask each reader of this note to consider his or her own reading habits. How many articles or books do you read each year outside your principal field in the discipline? The truth is that the soft-science manuscript on the French party system or Chinese-Russian relations is of no wider interest in the discipline as a whole than the hyperscientific stuff the APSR has been churning out over the last decade. We all belong to fairly exclusive minorities, and any realistic change in editorial policy must take that into account.

Since the general interest doctrine has worked against the publication of soft-science research, let's drop it. Assure every author that his or her submission to the APSR will be refereed by people in the same field and, to the extent possible, by people who are not methodologically averse to the type of work the author is doing. I suspect that the range of submissions will expand quickly. Moreover, this policy is one whose implementation the Publications Committee could easily verify. If the editors would like to add general interest to the journal, I suggest that they experiment with different types of articles, as the American Historical Review has done in recent years, highlighting certain debates in that discipline. But don't apply an unrealistic general-interest doctrine to the consideration of original research. What would happen if every manuscript went to a refereeing panel composed of one soft-science comparativist, one hard-science Americanist, and one scholar of classical philosophy? Rather than articles of general interest, I suspect that we would get articles of no interest-vanilla ice cream from cover to cover-and not enough of them to fill the journal at that.

Even a verifiable change in editorial policy may not be sufficient structural reform to balance the contents of the APSR. Nine years after the presentation of Betts's memo, I am skeptical of this organization's capacity to reform itself. It is gratifying to read that Professor Jervis, too, favors reform, but Betts found in 1991 that several recent APSA presidents did types of research that were unwelcome in the Review. It made no difference. Structural change must back up good intentions, and there have been many good ideas for structural change. The idea of multiple editors, one per field, has merit. How can one person in American politics or any other field pretend to make intelligent decisions on manuscripts from every corner of the discipline? But the best structural change would be to make the APSR, and the Association as a whole, regularly answerable to its mass membership.

The ways to do this in relation to the journal are to subject the editorship(s) to a mass vote and to make subscriptions to the APSR optional for members, just like subscriptions to the Personnel Services Newsletter. Optional subscriptions would give each of us a chance to vote on the fairness of the APSR's editorial policy every year when we renew our memberships. This reform should come in addition to those mentioned above, not as an alternative to them. Why are the people in charge of this Association so determined to force its members to take a journal that many of them clearly do not want? The inability of the mass membership to decide major policy questions in a regular, systematic way is the ultimate source of most of the complaints against the American Political Science Association.

The best guarantee of the APSR's reform is to force it to sell subscriptions on an open market. If it is unable to produce a useful, representative product, let it suffer the same pain of rejection experi- 
enced by so many of its would-be contributors. Let the editors, and not just the contributors, worry about their acceptance rate.
Gregory J. Kasza,

Indiana University

November 6, 2000

\section{Discipline out of Touch with Real-World Concerns}

I am a graduate student nearing completion of my Ph.D., and the recent discussion regarding APSA's institutional exclusiveness and nearobsession with statistical methods resonates strongly with me. As an undergraduate, I majored in English and minored in political science and economics, and chose to enter a political science graduate program because of a passion for politics and intellectual inquiry. However, this initial (and somewhat youthful) idealism has gradually been supplanted by an ever-growing cynicism regarding both the discipline and my own function as one of its adherents.

Mr. Perestroika's claims regarding the hegemonic status accorded statistical methodologies deserve some comment here. During my tenure as a graduate student, I have encountered many "political scientists" whose fixation on quantitative tools blinds them to all else. They remain completely oblivious to the complexities inherent in social and political phenomena that we, as social scientists, are ostensibly charged with understanding and explicating. Additionally, I have attended numerous APSA meetings and listened to so-called "luminaries" in the field tout their "parsimonious and elegant" models that bear little resemblance to the world I inhabit. It is gratifying to realize that I was not alone in thinking that many of these studies were both uninteresting and futile.

Incidentally, although I have presented individual papers at APSA meetings in the past, an analytically rigorous panel proposal on transnational social movements that I submitted to the 2000 meeting was unceremoniously rejected. While I do not think that my own research is particularly worthy of public approbation, the other panelists included accomplished scholars such as Saskia Sassen and Yossi Shain, both of whom have made significant contributions to our understanding of important contemporary political issues. This offhand dismissal seems indicative of APSA's preoccupation with methodology at the expense of

\section{Ideas for Reforming APSA Officer Elections}

Notably missing from your mission statement is the thought of staging competitive elections for key offices, including president, of the APSA.

It is ironic that the APSA, many of whose members (myself included) study and write on elections, is one of the few academic societies I know that does not nominate more than one candidate for president. I, personally, have had experience with seven societies, with collectively 600,000 members, that not only mandate competitive elections but also use approval voting in them.
I won't rehearse the advantages of using approval voting when there are more than two candidates to find consensus choices. Suffice it to say that none of the societies that has adopted approval voting (beginning about 15 years ago) has switched to another voting system.

In light of the Perestroika protest, may I suggest that the Strategic Planning Committee consider the use of competitive elections by the APSA and possible voting systems for implementing them. A recent popular discussion of alternative voting systems can be interesting, timely, and politically relevant scholarship.

I am extremely excited about this revolution from within and lend it my unequivocal support. However, I will not be formally affiliated with the discipline in the near future. While I have been exceedingly fortunate to have a supervisor who shares my intellectual Weltanschauung, I have decided not to pursue a career in academia for many of the reasons highlighted by Mr. Perestroika. Finally, I am a woman and a minority (who did not grow up in the United States), and am amazed at how out of touch many American-trained political scientists are with "real-world" politics. As those of us who study ethnic conflict are keenly aware, these real-world politics affect people's lives in tangible and sometimes terrible ways.

I commend Mr. Perestroika and others for having the courage to give voice to opinions that many of us have long held in silence.

Therese S. Gunawardena-Vaughn, University of Texas, Austin

found in two articles now posted on the web:

Mackenzie, Dana. 2000. "May the Best Man Lose"<www.discover.com/ current_issue/index.html>. Discover 21(November 2000): 85-91.

Guterman, Lila. 2000. "When Votes Don't Add Up: Mathematical Theory Reveals Problems in Election Procedures" <http://chronicle.com/ free/v47/i10/10a01801.htm>. The Chronicle of Higher Education, November 3, A18.

Steven Brams, New York University November 6, 2000 


\section{American Association of Political Consultants Joins APSA's Interdisciplinary Membership Program}

In December 1999, the American Association of Political Consultants joined APSA's existing sister associations (the American Historical Association, the American Sociological Association, and the American Society of International Law) in offering joint memberships at a substantial discount. APSA has arranged for members like you to be able to join any of the following scholarly associations without breaking your bank.

AMERICAN HISTORICAL ASSOCIATION

AS A MEMBER OF AHA, you will receive the following publications: The American Historical Review; Perspectives; AHA Annual Meeting Program. You will also receive special member prices for other publications.

AHA Associate Member Dues $\$ \$ 47.00$

\section{AMERICAN SOCIOLOGICAL ASSOCIATION}

AS A MEMBER OF ASA, you will receive Footnotes (ASA's newsletter), one journal of your choice, and the Preliminary Program for the ASA annual meeting. Choose ONE of the following journals: American Sociological Review, Contemporary Sociology, Social Psychology Quarterly, Sociological Methodology, Sociological Theory, Teaching Sociology, Sociology of Education, Journal of Health and Social Behavior. You may also join sections, register for the annual meeting, and subscribe to other journals all at discounted member rates.

ASA Interdisciplinary Membership Dues: $\$ \$ 50.00$
AMERICAN SOCIETY OF INTERNATIONAL LAW AS A MEMBER OF ASIL, you will receive the premier quarterly in the field, the American Journal of International Law, and the ASIL Newsletter, published five times a year. You will have the ability to interact with over 4,500 members worldwide involved in all branches of international law, receive discounts on the ASIL Annual Meeting, the Hague meeting and other Society sponsored events, and qualify for member discounts on ASIL's other publications.

ASIL Interdisciplinary Member Dues: $\quad \$ 55.00$

AMERICAN ASSN. OF POLITICAL CONSULTANTS AS A MEMBER OF AAPC, you will receive a six-week subscription to Campaign Insider. You will be listed on the Campaigns \& Elections web site and in Political Pages, and will receive discounts to the AAPC annual conference, the AAPC annual Pollie Awards, all American League of Lobbyists events, and on subscriptions to Roll Call, The Hill, and The Target Book. AAPC Associate Member Dues $\$ \$ 60.00$

\section{I would like to become an interdisciplinary member of the :}

AHA for $\$ 47.00$

ASA for $\$ 50.00$. Selected Journal:

ASIL for $\$ 55.00$

AAPC for $\$ 60.00$

\section{Method of Payment:}

Check (payable to APSA)

$\square$ Visa $\square$ Mastercard $\square$ American Express

card number Expiration Date

signature

\section{Register the membership in the name of:}

Name:

APSA Member Number

Address

City State

Zip Country

Phone:

Fax:

Email:

Send the completed form to:

APSA MEMBERSHIP

P.O. Box 631125

Baltimore, MD 21263-1125
Phone: 202.483.2512

Fax: 202.483.2657

Email: membership@apsanet.org

Web: www.apsanet.org 